\title{
Legal Status and Overview of World Trade Organization Disputes Involving Subsidies in the Renewable Energy Sector
}

\author{
Giga Abuseridze \\ Rìga Stradiňš University, \\ Doctoral Study Programme \\ "Legal Science", Georgia \\ giga.abuseridze@yahoo.com
}

\begin{abstract}
This article is divided in several sections. The first one offers an overview of the disputes of the World Trade Organisation involving subsidies in the renewable energy sector. The second one focuses on the recent decisions reached in Canada-Renewable Energy and Legal Analysis of the Renewable Energy Decision. feed in tariff.

Keywords: World Trade Organisation, renewable energy, dispute settlement body,

\section{Introduction}

So far, the Dispute Settlement Body (DSB) of the World Trade Organisation (WTO) has been presented with a few disputes regarding renewable energy, while none has been presented in relation to a measure supporting fossil fuels and especially oil. On the other hand, several disputes concern export and local content subsidies. The finding and conclusion reached by the WTO panel and Appellate Body in these cases can surely help clarify the WTO's approach towards such types of governmental support. What can be concluded from the analyses below is that both the panel and Appellate Body have interpreted the rules quite narrowly, so as not to leave much space to state's policies in favour of renewable. This is despite the inarguable evolution of the WTO case law towards its deep and final objectives represented by the WTO preamble when it comes
\end{abstract}


Giga Abuseridze. Legal Status and Overview of World Trade Organization

Disputes Involving Subsidies in the Renewable Energy Sector

to assessing the relationship between trade and non-trade concerns, and especially the environment. ${ }^{1}$

The first two disputes are related to the Canadian renewable energy generation sector: Canada Feed in Tariff Program and Canada-Renewable Energy. ${ }^{2}$ In both disputes, the Canadian measures challenged by the European Union (EU) and Japan, respectively, as well as the WTO provisions, violations of which have been complained of, are the same. Both the EU and Japan challenged the FIT programme established by the Canadian province of Ontario in 2009 providing for the guaranteed, long-term pricing for the output of renewable energy generation facilities that contained a defined percentage of domestic content. The complainants deemed this programme to be inconsistent with Article 3.1 (b) ${ }^{3}$ and $3.2^{4}$ of the Agreement on Subsidies and Countervailing Measures (SCM Agreement) ${ }^{5}$ because of the local content requirement present in the feed in tariff system ${ }^{6}$. The panels circulated their Reports on 19 December, 2012, rejecting the claim of the complaint that the challenged measures were to be considered subsidies, according to the SCM Agreement.

In 2010, another dispute was initiated; this time by an investigation carried out by the United States Trade representative (USTR) on 15 October, 2010, which covered a broad variety of Chinese policies and practices affecting trade and investment in the wind power technology sector. ${ }^{7}$ As a follow-up to this investigation, the United States held WTO consultations with China on 16 February, 2011. ${ }^{8}$ However, such consultations did not cover all the issue raised in the investigation but rather focused on subsidies. The US made a clear view that the subsidies, provided to Chinese wind turbine

1 Towards a Universal Justice? Putting International Courts and Jurisdictions into Perspective. Edited by Dario Moura Vicente. Brill / Nijhoff, 2016, p. 334-345.

2 Panel Report. Canada Measures Relating to the Feed-in Tariff Program (Canada Feed-in Tariff Program), WT/DS ${ }_{426}$ R (Dec. 19, 2012) and appellate body report, WT/DS ${ }_{426} / \mathrm{AB} / \mathrm{R}$ (May. 6, 2013); Panel Report. Canada - Certain Measures Affecting the Renewable Energy Generation Sector (Canada-Renewable Energy), WT/DS 412 /R (Sep. 3, 2010) and Appellate body Report, WT/DS $412 /$ $\mathrm{AB} / \mathrm{R}$ (Dec. 19, 2012).

3 SCM Agreement, Article 3.1 (b) reads: "Except as provided in the Agreement on Agriculture, the following subsidies, within the meaning of Article 1, shall be prohibited 9b) subsidies contingent, whether solely or as one of several other conditions, upon the use of domestic over important goods."

4 According to SCM Agreement, Article 3.2, "The member shall neither grant nor maintain subsidies referred to in paragraph 1."

5 Agreement on Subsidies and Countervailing Measures, Apr. 15, 1994, Marrakesh Agreement Establishing the World Trade Organisation, Annex 1A, 1869, U.N.T.S. 14.

6 The other claims regarded the alleged violation of Article 2.1 of the Agreement on Trade Related Investment Measures (TRIMS) and GATT Article III; 4.

7 The USTR investigation was based on a petition filed on September 9, 2010 by the USW. C. Moyer, J. Wanging \& T. P. Stewart, on behalf of the United Steel, Paper and Forestry, Rubber, Manufacturing, Energy, Allied Industrial and Service Workers International Union.

${ }^{8}$ China-Measures Concerning Wind Power Equipment, Supra note 66. 
manufactures under the Special Found Programme through which Chinese manufacturers of wind turbines and of its components can receive multiple grants, were prohibited because they were conditioned upon the use of domestic over imported goods (and therefore prohibited according to Article 3 of the SCM Agreement). Following those consultations, Chine took action formally revoking legal measure that had created the Special Fund programme.

Two new requests for consultation were presented in 2012 and 2013: European Union and Certain Member States - Certain Measures Affecting the Renewable Energy Generation Sector ${ }^{9}$ and India - Certain Measures Relating to Solar Cells and Solar Modules $^{10}$. In the first case, Chine requested consultations with the EU, Greece and Italy regarding certain feed in tariff programme implemented by a number of the EU member states in the renewable energy sector; while in the second, the US challenged Indian measures relating to domestic content requirement under the Jawaharial Nehru National Solar Mission (NSM) for solar cells and solar modules.

\section{Disputes Involving Canada and Renewable Energy: Is there Room for Change?}

All the disputes briefly described above involve subsidies related to renewable energy enterprises, considered to be prohibited according to Article 3 of the SCM Agreement due to the local content requirement prescribed there. ${ }^{11}$ However, the China Wind dispute, the official position of the panel is unknown because China removed the measure at stake after consultations with the US, and the last two disputes are still at request for a consultation stage, the panel and Appellate Body Reports on Canada Feed in Tariff Programme and Canada-Renewable Energy, offers interesting insights on the problems of subsidies in the renewable energy sector. In order to decide whether subsidies generally prohibited might be permitted because of their "green" nature, we will answer two questions: whether measures supporting renewable energy are to be considered as "subsidies" according to the SCM Agreement, and if they are, whether those can still be justified.

Regarding the first part of a question: The SCM Agreement provides definition of "subsidies" in Article 1: a subsidy exists whenever a financial contribution is made by a government or any public body within the territory of a member, which confers

9 Request for consultation by China, European Union and Certain Member States - certain Measures Affecting the Renewable Energy Generation Sector, WT/DS ${ }_{452} /{ }_{1}$ (Nov. 5, 2012).

${ }^{10}$ Request for consultation by United States, India certain Measures Relating Solar Cells and Solar modules, WT/DS456/1 (Feb. 6, 2013).

${ }^{11}$ SCM Agreement, Article 3,1 (b) identifies the following subsidies as prohibited: "Subsidies contingent, whether solely or as one of several other conditions, upon the use of domestic over imported good." 
a benefit. Moreover, according to Article 1.2, only a measure that is a "specific subsidy", as defined in Part I of the SCM Agreement, is a subject to the WTO's subsidies discipline. In order to verify whether measures adopted to support trade in renewable energy fall within the scope on the SCM Agreement, two requirements need to be analysed: (a) the existence of a financial contribution of public nature, and (b) the existence of a benefit.

Regarding the second question: The complainants in Canada-Renewable Energy and Canada Feed in Tariff Program disputes were not able to prove the existence of a benefit for the recipient of the government measure, and, therefore, there was no violation of the SCM Agreement by the Government of Ontario. It might be, nevertheless, interesting to conduct a purely theoretical reasoning over the possibility to justify measures supporting renewable energy if they were to be found to be "prohibited subsidies" according to ACSM Article 1 and 3. In particular, I would like to address issues which have proved to be extremely controversial: the possibility to apply the general exceptions set out in GATT Article XX to the ACSM, since the latter lacks its own exceptional clause.

Can GATT Article XX be applied to a subsidy, which goes beyond the scope of the Agreement? In other words, can GATT Article XX integrate the provisions of the SCM Agreement? Various arguments can be made against such applicability. First of all, one might stress the fact that in order for GATT Article XX to be applied, the SCM Agreement should explicitly recall it, as it happens in the Agreement on Sanitary and Phytosanitary measures (SPS Agreement), which makes express reference to GATT Article XX(b) in Articles 1 and 2.4. ${ }^{12}$ Furthermore, not only does the SCM Agreement not mention such provision but, in Article 3.1, on prohibited subsidies, it is specifically excluded from the scope of the provisions provided in the Agreement of Agriculture. Finally, the Agreement on subsidies used to have its own exception, enshrined in Article 8, is now no longer in force. The existence of a provision similar to Article XX but designed exclusively for the SCM Agreement could be seen as a sign of inadequacy and eventually inapplicability of GATT Article XX. ${ }^{13}$

On the other hand, a few arguments have been proposed in favor of the applicability of GATT Article XX to the SCM Agreement: the first one relates to a general principle of international law, the second one is the result of a purely logical reasoning, and the last one is based on the WTO case law. First, we need to consider the hierarchy of the different agreements belonging to the WTO legal framework. As a matter of fact, the principle of lex specialis derogat legi generali, widely applied by international courts and tribunals,

12 According to SPS Article 1, members desire, to elaborate rules for the application of the provisions of GATT 1994 which relate to the use of sanitary or phytosanitary measures, in particular the provisions of Article XX (b).

13 Rubini, L. The Subsidization of Renewable Energy in the WTO: Issues and Perspectives, supra note 24 , at 34 . 
is a broadly accepted customary international law principle of treaty interpretation. ${ }^{14}$ The GATT is applied as soon as trade in goods is affected, and can be therefore classified as lex generalis, while the SCM Agreement as well as other agreements such as the SPS, the TBT and others have a specific scope of application and therefore qualify as lex specialis. This means that, while the provisions of the SCM Agreement as lex specialis take precedence over those of the GATT lex generalis in case conflict, the GATT remains always applicable to fill in possible gaps, where the SCM Agreement does not specifically contemplate otherwise. The second argument is purely logical. It stems from the analysis of the different measures covered by the two agreements (GATT and SCM Agreement) and from the consideration that denying the applicability of the exceptions set out in GATT Article XX to subsidies would create irreversible and unjustified policy inconsistencies. As a matter of fact, the GATT covers measures such as total bans and quotas which are widely known as more restrictive and trade distorting than subsidies. Needless to say that such an approach would end up allowing more distorting measures and banning less distorting ones. ${ }^{15}$

Finally, the last argument is based on the WTO case law. In the China Publications and Audiovisual Products ${ }^{16}$ dispute, the Appellate Body agreed that Article XX of the GATT could be applied to China's Protocol of Accession (in particular to Article 5.1), and for the first time it showed a positive attitude towards the idea that such provision might be applicable beyond the scope of the agreement. There is still a crucial difference between China's Accession Protocol and the SCM Agreement: the latter like the other WTO agreement does not include a general "without prejudice clause" as written in China's Accession Protocol. Whether this obstacle could be overcome or not based on the legal relationship between the SCM Agreement and GATT provision is still debated.

It follows that the WTO treaty structure is complex and the relationship between the provisions of the WTO Agreements is not at all clear. On the one hand, the WTO panel and Appellate Body are not likely to agree on the application of Article XX to the SCM Agreement provisions, since, in the interpretation of the WTO agreements, they have often adopted a quite narrow approach that appears to apply the rules of the Vienna Convention on the Law of Treaties (VCLT) rather mechanically. On the other hand, the recent ruling in the aforementioned China Publications and Audiovisual Products case represents a "welcome development in WTO jurisprudence". ${ }^{17}$ Undoubtedly, however, allowing GATT

${ }^{14}$ Pauwelyn, J. Conflicts on Norms in Public International Law: How WTO Related to Other Rules of International Law, 2003, p. 385.

${ }^{15}$ Howsem, R. Climate Change Mitigation Subsidies and WTO Legal framework: A Policy Analysis, International Institute for Sustainable Development, 2010, p. 13.

16 Appellate Body Report, China-Measures Affecting Trading Rights and Distribution Services for Certain Publications and Audiovisual Entertainment Products (China Publications and Audiovisual Products), WT/DS ${ }_{363} / \mathrm{AB} / \mathrm{R}$ (Dec. 21, 2009).

17 Ya Qin, J. Pushing the Limits of Global Governance: Trading Rights, Censorship and WTO Jurisprudence, supra note 94, at 293. 
Article XX to be used to justify any WTO violation even beyond the list of objectives mentioned therein would confer considerable power to the panel and the Appellate Body, increasing the discretion they already exercise in the weighting and balancing activity required under Article XX.

\section{Legal Analysis of Renewable Energy Decision}

The Canada-Renewable Energy case is about two markets: (1) the market for renewable energy equipment production and investment, and (2) the market for electricity. The renewable energy equipment market is a global market, and Canada has allowed its province Ontario to erect discriminatory barriers against importation of those products (barriers that can only make renewable energy more costly in Canada). By contrast, the electricity market has traditionally been local, with cross-border electricity trade limited by geography and grid connection infrastructure. While the economic impact of a FIT may primarily be to incentivize investment in new renewable energy capacity and equipment installation, the policy is implemented with payments based on electricity generation.

In its decision, the Appellate Body addresses mainly the market for electricity, as that is where the subsidy would be legally defined. However, the decision makes a distinction between electricity from certain renewable sources and other generation. Indeed, the Appellate Body seems to split the market between those two sources. This is an important development, because electrical current from the two sources is physically identical and interchangeable in use.

\section{TRIMS Agreement and GATT Article III}

Canada-Renewable Energy marked the first Appellate Body decision under the TRIMS agreement, thereby laying precedents for future jurisprudence on the application of the TRIMS non-discrimination disciplines. The Appellate Body reversed the panel so as to reduce the scope of the derogation for government procurement in GATT Article III. This holding has implications for TRIMS because that agreement and GATT Article III are so closely interconnected.

The panel began its evaluation under the TRIMS Agreement by considering whether the FIT program was in fact an investment program and, if so, whether it was traderelated. (Canada did not contest that the measure fit within the scope of the TRIMS Agreement.) A previous panel, Indonesia-Autos in 1998, took the same approach, but the Autos panel decided that the contested measure was an investment measure based on its announced purpose and legislative text. ${ }^{18}$ By contrast, the Renewable Energy panel decided that the FIT was an investment measure not only based on legislative record, but also considering the evidence that Ontario's scheme had in fact attracted investment in

18 Panel Report, Indonesia - Autos, DS64, para. 14.80. 
equipment manufacturing. Like the Autos panel, the Renewable Energy panel found that the investment measure was trade-related based on its minimum local content requirement. These findings were not reviewed by the Appellate Body.

The TRIMS Agreement lacks any substantive disciplines independent of the GATT; therefore, evidencing a violation of GATT Article III or XI is necessary to show a violation of TRIMS Article 2. Ontario's measure was not a quantitative restriction, so if there was a violation of GATT, it had to be a violation of Article III:4 (national treatment). The key question before the panel was how to apply the language in Article III:8(a), which carves out from the disciplines $\mathrm{f}$ Article III certain activity related to government procurement the Appellate Body refers to Article III:8(a) as a "derogation". ${ }^{19}$

Canada's defense to the cause of action under TRIMS was based solely on Article III:8(a); namely, due to the nature of the program being a market created by and for the government and its entities, it was not a subject to Article III's obligations. The EU offered an expansive reading of TRIMS Article 2.2 and the TRIMS Illustrative List that suggested a discriminatory measure on the Illustrative List could be found to be a violation of GATT Article III:4 irrespective of the Article III:8 procurement derogation. In its decision, the panel rejected that argument, and its analysis was upheld by the Appellate Body. ${ }^{20}$ In doing so, the Appellate Body suggested it was a providing a "harmonious" interpretation of TRIMS Articles 2.1 and 2.2 together. ${ }^{21}$ Moreover, the Appellate Body held that the TRIMS Illustrative List is not a closed list and that GATT Article III:8(a) provides "rights" to WTO Members.

Thus, the availability of Article III's procurement derogation was the central feature of the TRIMS and GATT analysis. This question was nearly a tabula rasa for the WTO dispute system, as no previous WTO jurisprudence on GATT Article III:8(a) had occurred. As a result, both the panel and the Appellate Body devoted considerable attention to the interpretation of Article III:8(a). Although the Appellate Body upheld the panel's conclusion that the challenged measure did not fit within the terms of the Article III:8(a) derogation, it declared that the panel had erred on a key analytical point.

In determining the applicability of GATT Article III, the panel divided the analysis into three prongs: first, whether the measure is a law, regulation, or requirement governing procurement; second, whether the measure involves procurement by governmental agencies; and third, whether the procurement is undertaken for governmental purposes and not with a view to commercial resale. On the first prong, the panel found that the domestic content requirement for renewable energy equipment is a requirement

19 Appellate Body Reports. Canada - Renewable Energy / Canada - Feed-in Tariff Program, para. 5.56 (noting that this term does not indicate who bears the burden of proof).

${ }^{20}$ Panel Reports. Canada - Renewable Energy / Canada - Feed-in Tariff Program, para. 7.120; Appellate Body Reports, para. 5.33.

${ }^{21}$ Appellate Body Reports. Canada - Renewable Energy / Canada - Feed-in Tariff Program, para. 5.26. 
governing the procurement of electricity because there is "very clearly a close relationship" between the electricity allegedly being procured and the domestic content requirement on energy generation equipment. On the second prong, the panel found that the measure constitutes procurement by government agencies. On the third prong, the panel reasoned that if the purchase had been done with a view to commercial resale, then such a purchase cannot be for governmental purposes. Focusing on the issue of commercial resale, the panel considered and rejected several arguments by Canada that the nature of the market undermined the commerciality of the sale. Consequently, the panel ruled that the resale of electricity produced through the FIT program is "commercial" and that the government indeed earns a profit. Thus, the Canadian Article III:8(a) defense was found to have failed on the third prong, and the panel did not rule on the existence of "governmental purposes".

The applicability of the Article III:8(a) defense was appealed by all three parties. Explaining that Article III:8(a) was a derogation rather than a justification, the Appellate Body provided what it called a "holistic" interpretation of the key terms in Article III:8(a). The Appellate Body's dicta will surely guide future panels. The most important conclusion reached by the appellators was that since both the obligations in Article III and the derogation in III:8(a) refer to discriminatory treatment of products, the same discriminatory treatment must exist with both rules. ${ }^{22}$ Put another way, the product of foreign origin being discriminated against must be in a competitive relationship with the product purchased by the government.

Applying its interpretation to the facts, the Appellate Body noted that the discriminatory treatment (in the form of minimum content) applies to renewable energy equipment, while the government procurement concerns electricity. Since electricity is not the same or as a competitive product to the electricity generating equipment that is being treated less favorably, the Appellate Body reversed the panel on the first prong, holding that the discriminatory measures were not covered by the Article III:(8)(a) derogation. The Appellate Body also reversed as "moot" all of the other legal interpretations by the panel of Article III:8(a).

The remainder of the panel's finding with regard to TRIMS Article 2.1 and Article III:4 was not challenged by Canada on appeal, and the Appellate Body made it clear that this part of the panel's analysis "stands". Specifically, based on its conclusion that Article III:8(a) did not apply, the panel had analysed the Ontario measure under Article III:4. The panel found that mere participation in the FIT program was an "advantage" under the chapeau of Article 1(a) of the TRIMS Illustrative List and that compliance with the domestic content requirements was necessary in order to obtain this advantage. ${ }^{23}$

${ }^{22}$ Appellate Body Reports. Canada - Renewable Energy / Canada - Feed-in Tariff Program, para. 5.63. The Appellate Body's restatement of Article III:8(a) is summarized in ibid., para. 5.74.

23 Panel Reports. Canada - Renewable Energy / Canada - Feed-in Tariff Program, para. 7.165. 
Giga Abuseridze. Legal Status and Overview of World Trade Organization

Disputes Involving Subsidies in the Renewable Energy Sector

Therefore, the panel concluded that the domestic content requirement of the FIT was inconsistent with Article III:4 and thereby also inconsistent with TRIMS Article 2.1. These findings were upheld.

\section{SCM Agreement Articles 1 and 3}

The cause of action against the FIT contracts was that they violate SCM Agreement Article 3.1(b), which forbids providing a subsidy contingent on local content. In adjudicating this claim, neither the panel nor the Appellate Body reached this central issue, because neither was able to validate the existence of a subsidy. The SCM Agreement defines a subsidy in Article 1 as generally requiring the two prongs of a financial contribution from the government and a benefit to a recipient. Alternatively, a subsidy can also be shown if, instead of a financial contribution, there is "any form of income or price support in the sense of" GATT Article XVI (notification of subsidies). If found to be a subsidy, then in view of the embedded LCR, the Ontario FIT would automatically be prohibited under the SCM Agreement. (A separate question, not addressed in the adjudication, would ask whether a FIT without an LCR would be specific and actionable under the SCM Agreement with regard to trade in electricity.)

A key issue in this case was how, if at all, Ontario's FIT contracts come within the statutory definition of financial contribution. The SCM definitional provisions are as follows: [A] subsidy shall be deemed to exist if:

(a) there is a financial contribution by a government or any public body within the territory of a Member (referred to in this Agreement as "government"), i.e., where:

(i) a government practice involves a direct transfer of funds (e.g., grants, loans, and equity infusion), potential direct transfers of funds or liabilities (e.g., loan guarantees);

(ii) government revenue that is otherwise due is foregone or not collected (e.g., fiscal incentives such as tax credits);

(iii) a government provides goods or services other than general infrastructure, or purchases goods;

(iv) a government makes payments to a funding mechanism, or entrusts or directs a private body to carry out one or more of the type of functions illustrated in (i) to (iii) above, which would normally be vested in the government and the practice, in no real sense, differs from practices normally followed by governments. ${ }^{24}$

All three litigants agreed that the contracts were financial contributions, but the three governments offered different views as to the proper legal characterisation between (i) and (iii) above.

${ }^{24}$ SCM Agreement, Article 1.1(a)(1) (internal footnote omitted). 
Giga Abuseridze. Legal Status and Overview of World Trade Organization

Disputes Involving Subsidies in the Renewable Energy Sector

The Appellate Body's roadmap for how a panel should conduct the benefit analysis in future FIT cases has been summarised in Table 1.

Table 1. Appellate Body's suggested hierarchy for selecting comparator for benefit analysis

\begin{tabular}{|l|l|}
\hline \multicolumn{1}{|c|}{ Source of benchmark } & \multicolumn{1}{c|}{ Options for determining relevant market price } \\
\hline 1. In-country benchmark & $\begin{array}{l}\text { (a) Market prices } \\
\text { (b) Administered prices determined based on price setting } \\
\text { mechanism } \\
\text { (c) Administered prices set through price discovery mechanism } \\
\text { such as competitive bidding or negotiated prices }\end{array}$ \\
\hline $\begin{array}{l}\text { 2. Out-of country benchmark when } \\
\text { government intervention is } \\
\text { distortive }\end{array}$ & $\begin{array}{l}\text { Same options, adjusted to prevailing conditions in the market } \\
\text { of the defendant country }\end{array}$ \\
\hline 3. Proxy construction & $\begin{array}{l}\text { Appellate Body does not elaborate but presumably provides } \\
\text { analysis based on costs plus profit }\end{array}$ \\
\hline
\end{tabular}

The Appellate Body did not analyse or rebut the noteworthy dissenting opinion in the panel report, which was emphasised by the previous Appellate Body jurisprudence regarding the marketplace. The dissenting judge has found that the FIT contracts do confer a benefit, because they bring high-cost and less efficient energy producers into the wholesale electricity market when they would not otherwise be present. In addition, an anonymous lawyer has pointed out that although a competitive market might not achieve all of the objectives that the government may have for the goods or services that are traded, such situation should not shield the related financial contributions from the benefit analysis required by the SCM Agreement.

\section{Conclusion}

Canada-Renewable Energy presented a challenging case in which preferential payments for electricity generation were being used to incentivise capacity investment in renewable energy, seeking to modify the generation mix in a historically regulated market. At the same time, a local content requirement was used to earmark the preferential treatment toward installing locally manufactured equipment. The panel and Appellate Body were rightly in agreement that the LCR constitutes a WTO violation but demurred as to whether a FIT constitutes a subsidy. The greater, unspoken question is whether WTO law poses obstacles for socially merited environmental policies, and the dispute process largely avoided this confrontation.

However, by avoiding the determination of whether an environmentally minded programme confers a benefit under the SCM, the Appellate Body may have opened the door for any number of well or poorly intentioned interventions. Cosbey and Mavroidis make this point forcefully, noting the incongruity of the Appellate Body's "acrobatic" analysis in trying to avoid finding the FIT a subsidy (2014: $32 \mathrm{n}$. 24). The irony is that this 
broadening of benefit analysis, and all the machinations regarding the relevant benchmarks in the electricity market, comes from a dispute that was fundamentally not about electricity trade, as the complainants have no electricity trade with Canada. Rather, the dispute was about eliminating non-tariff barriers to imported renewable energy generation equipment.

In fact, were the FIT found to be an electricity subsidy, it would be difficult to find a partner in electricity trade harmed by it and willing to challenge it. Meanwhile, one can also think of other policy designs that would have economically equivalent effects for the generation portfolio - namely, subsidies for renewable energy equipment and installation - and these would not trigger such analysis of the electricity market as the relevant market would be that of the manufactured equipment. Furthermore, in this situation, the subsidy would be viewed as a consumption subsidy, if also available to imports, rather than a production subsidy, and again a finding of harm would be challenging to identify.

Thus, had the Appellate Body found that the FIT were a subsidy, it is far from clear that this would have caused irreparable damage to renewable energy policy-making. Still, that judgment might have led to a useful conversation about aligning the SCM with internationally agreed-upon sustainable development goals. Instead, the Appellate Body, like the panel, seems to have tried to shield the WTO from broad criticisms from the environmental community. In the view of the author of this article, the environmental community would be more comfortable with a new discussion of including reasonable environmental exceptions in the SCM Agreement than with having to rely on judicial creativity on an ongoing basis.

These tensions include, first, the insufficiency of current interpretive tools. Second, the non-inclusion of energy or renewable energy in any WTO agreement makes it hard for WTO rules to fully acknowledge and value the specific obstacles faced by renewable energy producers and consumers. It is necessary to weight the positive externalities of renewable energy use against the negative ones created by fossil fuels when evaluating national policies, and the WTO still lacks a suitable mechanism to achieve this goal. Third, the need to condemn local content requirement should be balanced with the necessary, for developing countries and emerging economies, to develop or improve their own domestic renewable energy industry, and a subsidy programme completely void of a local content requirement would hardly help the country to develop its own domestic production and market. One possible solution could be to include a period of transition, provided for in the Protocol of Accession, where the local content requirements are accepted by the WTO until a certain level of development is reached. All these tensions show the fundamental inadequacy of existing WTO rules in this area. It is now indisputable that climate change is one of the most relevant problems to face contemporary world and it has to be addressed with new instruments, which, in the framework of the WTO, would require a change of course: leaving the current judicial status-quo behind with the adoption of a more flexible interpretation of the WTO Agreement toward sustainable development and protection of the environmental. 
Giga Abuseridze. Legal Status and Overview of World Trade Organization

Disputes Involving Subsidies in the Renewable Energy Sector

\section{Pasaules Tirdzniecības organizācijas strīdu, kas saistīti ar subsīdijām atjaunojamās enerǵijas nozarē, juridiskais statuss un pārskats}

\section{Kopsavilkums}

Šis raksts ir sadalīts vairākās sadaḷās. Pirmā sniedz pārskatu par Pasaules Tirdzniecības organizācijas strīdiem, kas saistīti ar subsīdijām atjaunojamās energíijas nozarē. Otrajā atspoguḷoti nesen pieṇemtie Kanādas lēmumi par atjaunojamo enerǵiju un trešajā juridiskā atjaunojamās enerǵijas analīze.

Atslēgvārdi: Pasaules Tirdzniecības organizācija, atjaunojamā enerǵija, strīdu izškịiršanas organizācija, tarifs.

\section{Literature}

1 World Trade Organization. Agreement on Subsidies and Countervailing Measures, Apr. 15, 1994. https://www.wto.org/english/docs_e/legal_e/24-scm.pdf

2 World Trade Organization. Agreement on Trade-Related Investment Measures. https://www.wto. org/english/docs_e/legal_e/18-trims_e.htm

3 World Trade Organization. Marrakesh Agreement Establishing the World Trade Organization, Annex 1A, 1869, U.N.T.S. 14. https://www.wto.org/english/docs_e/legal_e/04-wto_e.htm

4. Howsem, R. Climate Change Mitigation Subsidies and WTO Legal framework: A Policy Analysis. International Institute for Sustainable Development, 2010.

5 Pauwelyn, J. Conflicts on Norms in Public International Law: How WTO Related to Other Rules of International Law, 2003.

6 Rubini, L. The Subsidization of Renewable Energy in the WTO: Issues and Perspectives (August 3, 2011).

7 Ya Qin, J. Pushing the Limits of Global Governance: Trading Rights, Censorship and WTO Jurisprudence - A Commentary on the China-Publications Case. Chinese Journal of International Law, Vol. 10, 2011. 